\title{
Pochonia chlamydosporia var. chlamydosporia (Goddard) Zare \& W. Gams for the management of lettuce infected with Meloidogyne javanica (Treub, 1885)
}

\author{
José R. Viggiano ${ }^{1}$, Leandro G. Freitas ${ }^{1}$, and Everaldo A. Lopes ${ }^{2 *}$
}

\begin{abstract}
The application of the nematophagous fungus Pochonia chlamydosporia var. chlamydosporia (Goddard) Zare \& W. Gams during seedling production of vegetable crops can be an efficient approach to control root-knot nematode. The aim of this study was to evaluate the effect of treating seedlings and/or soil with bionematicide (wettable powder formulation) based on chlamydospores from isolate Pc-10 on the Meloidogyne javanica (Treub, 1885) control in lettuce (Lactuca sativa L.). Isolate Pc-10 was diluted in water and applied when watering the seedlings $\left(0,4.5,9.0,13.5\right.$, and $\left.18.0 \mathrm{~g} \mathrm{L^{-1 }}\right)$ and/or to the potted soil (5000 chlamydospores $\mathrm{g}^{-1}$ ) used for growing lettuce. The soil in each pot was infested with $3000 \mathrm{M}$. javanica eggs. The number of $M$. javanica eggs was reduced in lettuce roots when isolate Pc-10 was applied either to seedlings or soil; there was no interaction between application methods. The decrease in the number of eggs was proportional to the increase of isolate Pc-10 applied to seedlings with maximum reduction of $43.5 \%$ at the $18 \mathrm{~g} \mathrm{~L}^{-1}$ dose. When the fungus was applied to the soil, the number of eggs was reduced by $12.3 \%$. Increasing doses of isolate Pc-10 reduced the number of galls up to $21 \%$ with the $18 \mathrm{~g} \mathrm{~L}^{-1}$ dose. Applying bionematicide based on P. chlamydosporia isolate Pc-10 at $18 \mathrm{~g} \mathrm{~L}{ }^{-1}$ on seedlings controls $M$. javanica in lettuce.
\end{abstract}

Key words: Biological control, Lactuca sativa, nematophagous fungi, root-knot nematode.

\section{INTRODUCTION}

Sustainable management of root-knot nematode (Meloidogyne spp. Goeldi) can be accomplished by applying biological control agents such as Pochonia chlamydosporia (Goddard) Zare \& Gams (DallemoleGiaretta et al., 2013; Viggiano et al., 2014). This soilborne fungus parasitizes eggs and exposed females of root-knot nematode, which can drastically reduce the inoculum of the pathogen in the soil. Additionally, it produces chlamydospores that persist in the soil for long periods of time (Manzanilla-López et al., 2013).

Applying cereal grains colonized by the fungus controls root-knot nematode in vegetable crops (DallemoleGiaretta et al.,2010). However, this approach of delivering the antagonist can be cost-limiting. It is therefore important to evaluate strategies whose aim is to reduce the number of bioproducts based on P. chlamydosporia to

${ }^{1}$ Universidade Federal de Viçosa, Departamento de Fitopatologia, Campus UFV, Av. PH Rolfs s/n, 36570-000, Viçosa, Minas Gerais, Brasil.

${ }^{2}$ Universidade Federal de Viçosa, Instituto de Ciências Agrárias, Rod. MG 230, km 7, 38810-000, Rio Paranaíba, Minas Gerais, Brasil. *Corresponding author (everaldolopes@ufv.br).

Received: 3 July 2014.

Accepted: 22 December 2014.

doi:10.4067/S0718-58392015000200016 be applied in the field without decreasing the efficiency of the biological control agent.

In Brazil, lettuce (Lactuca sativa L.) is transplanted in the field with seedlings grown in polystyrene trays filled with organo-mineral substrates. Fungus application during the lettuce seedling production period can be an alternative for the management of root-knot nematode. The aim of this study was to evaluate the effect of treating seedlings and/or soil with bionematicide based on chlamydospores of P. chlamydosporia var. chlamydosporia isolate Pc10 (Pc-10) on the Meloidogyne javanica (Treub, 1885) control; this is one of the most important threats for lettuce production in tropical countries (Sikora and Fernández, 2005).

\section{MATERIALS AND METHODS}

The research study was carried out in a greenhouse with lettuce 'Regina 255' as the host plant and M. javanica as the pathogen to be controlled by Pc-10. A commercial bionematicide consisting of chlamydospores from the isolate Pc-10 (wettable powder formulation, mean concentration $3.1 \times 10^{8}$ viable chlamydospores $\mathrm{g}^{-1}$, Rizotec, Rizoflora Biotecnologia S.A., Viçosa, Brazil) was used. The bionematicide was diluted and applied when watering the seedlings and/or to the potted soil used for growing lettuce. 
Lettuce seedlings were grown in polystyrene trays filled with organo-mineral substrate $(\mathrm{pH} 5.54, \mathrm{C} / \mathrm{N} 23.81,5.5 \mathrm{~g}$ $\mathrm{N} \mathrm{kg}^{-1}, 2.6 \mathrm{~g} \mathrm{P} \mathrm{kg}^{-1}, 2.2 \mathrm{~g} \mathrm{~K} \mathrm{~kg}^{-1}$ ) previously moistened with $5 \%$ water (v:v). One seed was placed in each cell at a depth of $1 \mathrm{~cm}$. Plants were irrigated daily with a hose fitted with a sprinkler nozzle. For seedling treatment, the bionematicide was diluted in water (at $0,1.5,3.0,4.5$, and $6.0 \mathrm{~g} \mathrm{~L}^{-1}$ ), and $250 \mathrm{~mL}$ of the suspension was applied to the seedlings at 3,7 , and $12 \mathrm{~d}$ after sowing with a $500 \mathrm{~mL}$ polyethylene terephthalate bottle with a perforated lid. Seedlings were treated with $0,4.5,9.0,13.5$, or $18.0 \mathrm{~g} \mathrm{~L}^{-1}$ of the bionematicide suspension.

After the seedling stage, lettuce plants were grown in 80 plastic pots $(2 \mathrm{~L})$ filled with $2 \mathrm{~kg}$ of a soil:sand mixture (1:1, v:v). The mixture was previously fertilized with superphosphate $\left(6 \mathrm{~g} \mathrm{~kg}^{-1}\right)$ and treated with methyl bromide $\left(80 \mathrm{~cm}^{3} \mathrm{~m}^{-3}\right)$. Soil in each pot was infested with $3 \mathrm{~mL}$ of aqueous suspension containing $3000 \mathrm{M}$. javanica eggs. Then, $20 \mathrm{~mL}$ Pc-10 aqueous suspension was applied to the soil in 40 pots to provide 5000 chlamydospores $\mathrm{g}^{-1}$ soil, while soil in the remaining 40 pots was not treated with the fungus. The nematode inoculum consisted of eggs obtained from pure populations and collected from potted tomato plant roots (Solanum lycopersicum L. 'Kada') kept in a greenhouse and extracted by the Hussey and Barker (1973) technique modified by Boneti and Ferraz (1981). A lettuce seedling was transplanted in each pot $7 \mathrm{~d}$ after the soil was infested with the nematode. Plants were grown in a greenhouse and irrigated daily to maintain soil moisture at approximately field capacity.

To determine the number of colony-forming units (CFU) of Pc-10 in seedlings, substrate adhering to the root systems of 10 seedlings was collected $23 \mathrm{~d}$ after sowing; this established a substrate sample per dose of Pc-10 applied in the seedlings. The number of $\mathrm{CFU} \mathrm{g}{ }^{-1}$ substrate was determined according to the method described by de Leij and Kerry (1991) using a semi-selective medium (Gaspard et al., 1990).

On day 43 after transplanting seedlings, the weight of fresh shoots and roots and number of galls and eggs per plant were evaluated. The average minimum and maximum temperatures during the development of lettuce plants were 23.4 and $36.5^{\circ} \mathrm{C}$ for air and 24.4 and 32.5 ${ }^{\circ} \mathrm{C}$ for soil, respectively. Nematode eggs were extracted from lettuce roots according to Hussey and Barker (1973) and were counted under a dissecting microscope at $4 \mathrm{X}$ magnification. Root galls were counted with the naked eye. Rhizosphere soil samples were also collected to determine CFU g ${ }^{-1}$ soil of Pc-10 as described above.

The experiment was repeated twice in a completely randomized design with a $5 \times 2$ factorial arrangement $(\mathrm{Pc}-$ 10 doses applied to the seedlings $\times$ soil with or without Pc10) and eight replicates. Each experimental unit consisted of a pot with a lettuce plant. The experiment-treatment interactions were not significant $(P>0.05)$. Data from the two experiments were pooled for further analysis.
They were tested for normality of the error (KolmogorovSmirnov test), homogeneity of variances (Bartlett test), and subjected to ANOVA $(P<0.05)$. Data were analyzed by two-way ANOVA (Pc-10 doses in the seedlings $\times$ soil treatment and their interactions). Significant relationships between doses of bionematicide in seedlings and parameters were described by linear regression models.

\section{RESULTS AND DISCUSSION}

Increasing Pc-10 doses applied to seedlings increased fungus density in the substrate and varied from $4.2 \times$ $10^{4}$ to $10.5 \times 10^{4} \mathrm{CFU} \mathrm{g}{ }^{-1}$ substrate at doses of 4.5 and $18.0 \mathrm{~g} \mathrm{~L}^{-1}$, respectively (Figure 1). The fungus was not recovered from the untreated control, thus excluding the possibility of contamination among different treatments.

Lettuce root and shoot weight increased by $7.5 \%$ and $9.4 \%$, respectively, when Pc-10 was mixed with the soil (26.87 $\mathrm{g}$ in Pc-10 $\times 24.99 \mathrm{~g}$ in control and $73.36 \mathrm{~g}$ in Pc-10 $\times 67.02$ in control, respectively), regardless of the fungus application to seedlings. Pochonia chlamydosporia colonizes and produces chlamydospores in the rhizosphere of different plant species, such as tomato (Solanum lycopersicum L. 'Kada'), cabbage (Brassica oleracea L. var. capitata L.), kale (Brassica oleracea L.), corn (Zea mays L.), and sunn hemp (Crotalaria juncea L.) (Manzanilla-López et al., 2013). In addition, the fungus can promote plant growth (Maciá-Vicente et al., 2009). The present findings are consistent with those found in another study where the same fungus isolate was applied to lettuce (Viggiano et al., 2012) and suggest that Pc10 colonizes the lettuce rhizosphere and enhances plant growth.

The number of $M$.javanica eggs was reduced in lettuce roots when Pc-10 was applied either to the seedlings or soil; there was no interaction between application methods. The reduction in the number of eggs was proportional to

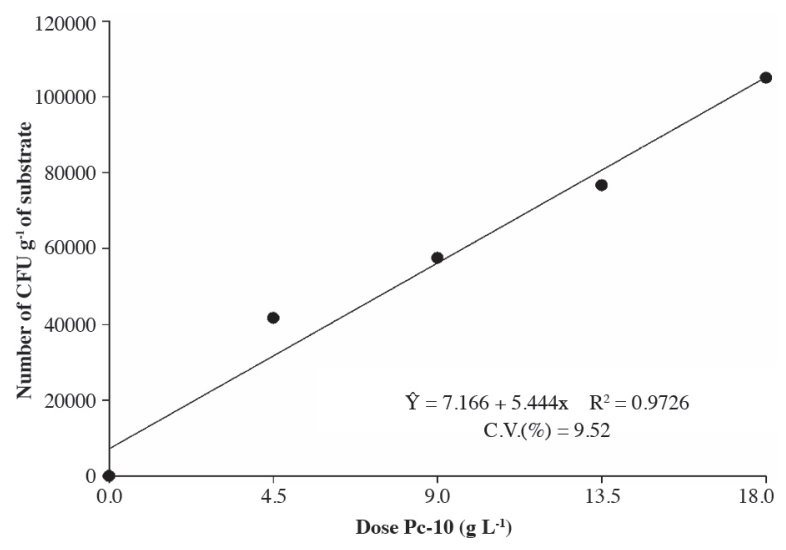

CV: Coefficient of variation.

Figure 1. Number of colony forming units (CFU) of Pochonia chlamydosporia var. chlamydosporia isolate Pc-10 per gram of substrate in lettuce seedlings watered with different doses of a suspension of bionematicide based on Pc-10 chlamydospores. 
the increase of Pc-10 applied to the seedlings (Figure 2), as observed in cucumber plants (Viggiano et al., 2014). The number of $M$. javanica eggs was $43.5 \%$ lower in plants treated with $18 \mathrm{~g} \mathrm{~L}^{-1} \mathrm{Pc}-10$. Applying the fungus to the soil reduced the number of nematode eggs by $12.3 \%$ (33 748 in Pc-10 × 38471 in control). Increasing doses of Pc-10 reduced the number of galls up to $21 \%$ with the $18 \mathrm{~g} \mathrm{~L}^{-1}$ dose, regardless of the additional soil application (Figure 3).

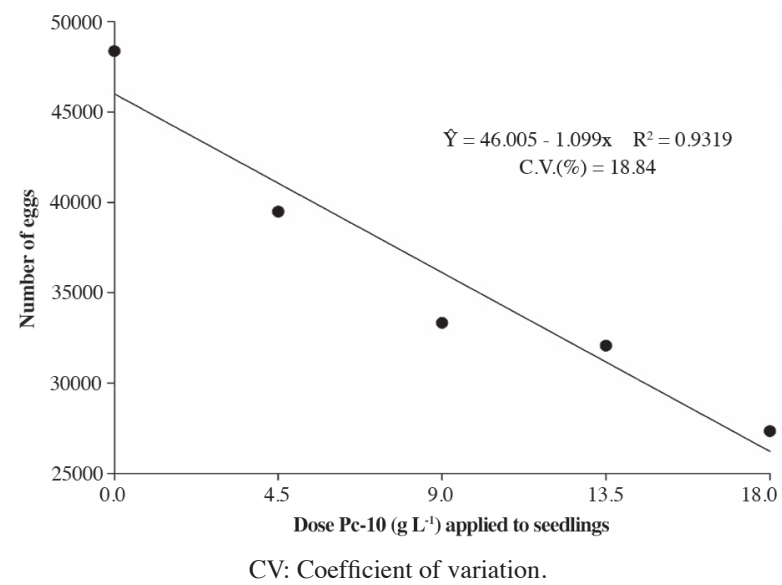

Figure 2. Number of Meloidogyne javanica eggs in lettuce roots treated with different doses of a suspension of bionematicide based on Pochonia chlamydosporia var. chlamydosporia isolate Pc-10.

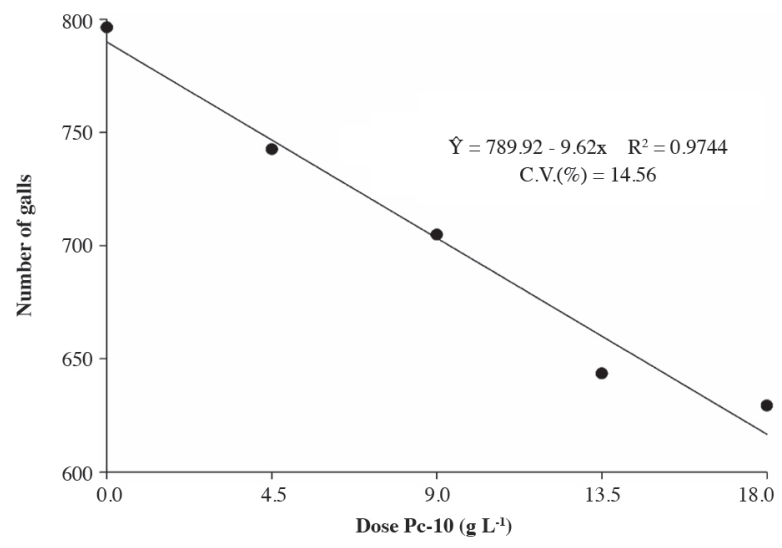

CV: Coefficient of variation.

Figure 3. Number of galls induced by Meloidogyne javanica in lettuce roots after applying different doses of a suspension of bionematicide based on Pochonia chlamydosporia var. chlamydosporia isolate Pc-10.

The application of $18 \mathrm{~g} \mathrm{~L}^{-1} \mathrm{Pc}-10$ in seedlings was primarily responsible for reducing the number of $M$. javanica eggs and galls in lettuce. Seedling treatment may have favored the establishment of Pc-10 in the soil and rhizosphere. As a consequence, it is likely that nematode eggs in the soil were colonized by the fungus before infective second-stage juveniles hatched $\left(\mathrm{J}_{2}\right)$, which explains the decrease in the number of galls and eggs. An additional application of the fungus to the nematodeinfested soil also reduced nematode reproduction, which corroborates findings of previous experiments involving Pc-10 and $M$. javanica in tomato (Dallemole-Giaretta et al., 2010; 2012). However, the overall effect on the $M$. javanica control was achieved when the fungus was applied to the seedlings, as observed in cucumber (Viggiano et al., 2014). It is likely that applying Pc-10 to seedlings of other vegetable crops can be an alternative for introducing the fungus in the substrate and in nematodeinfested soils, especially for plants which allow extensive colonization of $P$. chlamydosporia in their rhizosphere, such as tomato, kale, and cabbage (Manzanilla-López et al., 2013).

\section{CONCLUSIONS}

Isolate PC-10 controls Meloidogyne javanica in lettuce by applying bionematicide based on Pochonia chlamydosporia at a $18 \mathrm{~g} \mathrm{~L}^{-1}$ dose on seedlings.

\section{ACKNOWLEDGEMENTS}

Authors thank the Conselho Nacional de Desenvolvimento Científico e Tecnológico $(\mathrm{CNPq})$, for providing a scholarship to the first author, Paulo A. Ferreira for collaborating on the statistical analysis, and Rizoflora Biotecnologia S.A. for providing the bionematicide for the experiments.

\section{LITERATURE CITED}

Boneti, J.I.S., e S. Ferraz. 1981. Modificação do método de Hussey \& Barker para extração de ovos de Meloidogyne exigua de raízes de cafeeiro. Fitopatologia Brasileira 6:553.

Dallemole-Giaretta, R., L.G. Freitas, I.C. Cavallin, G.A. Marmentini, C.M.R. Faria, e J.T.V. Resende. 2013. Avaliação de um produto à base de Pochonia chlamydosporia, no controle de Meloidogyne javanica em alface e cenoura no campo. Nematropica 43:131-137.

Dallemole-Giaretta, R., L.G. Freitas, M.M. Coutinho, W.S. Neves, R.J.F. Zooca, e S. Ferraz. 2010. Efeito da farinha de sementes de abóbora e de Pochonia chlamydosporia no controle de Meloidogyne javanica. Nematologia Brasileira 34:91-97.

Dallemole-Giaretta, R., L.G. Freitas, E.A. Lopes, O.L. Pereira, R.J.F. Zooca, and S. Ferraz. 2012. Screening of Pochonia chlamydosporia Brazilian isolates as biocontrol agents of Meloidogyne javanica. Crop Protection 42:102-107. doi:10.1016/j.cropro.2012.06.002.

de Leij, F.A.A.M., and B.R. Kerry. 1991. The nematophagous fungus Verticillium chlamydosporium as a potential biological control agent for Meloidogyne arenaria. Revué de Nématologie 14:157-164.

Gaspard, J.T., B.A. Jaffee, and H. Ferris. 1990. Association of Verticillium chlamydosporium and Paecilomyces lilacinus with root-knot nematode infested soil. Journal of Nematology 22:207-213.

Hussey, R.S., and K.R. Barker. 1973. A comparison of methods of collecting inocula of Meloidogyne spp. including a new technique. Plant Disease Reporter 57:1025-1028.

Maciá-Vicente, J.G., L.C. Rosso, A. Ciancio, H.B. Jansson, and L.V. Lopez-Llorca. 2009. Colonisation of barley roots by endophytic Fusarium equiseti and Pochonia chlamydosporia: effects on plant growth and disease. Annals of Applied Biology 155:391-401. doi:10.1111/j.1744-7348.2009.00352.x. 
Manzanilla-López, R.H., I. Esteves, M.M. Finetti-Sialer, P.R. Hirsch, E. Ward, J. Devonshire, et al. 2013. Pochonia chlamydosporia: advances and challenges to improve its performance as a biological control agent of sedentary endo-parasitic nematodes. Journal of Nematology 45:1-7.

Sikora, R.A., and E. Fernández. 2005. Nematodes parasites of vegetables. p. 319-392. In Luc, M., R.A. Sikora, and J. Bridge (eds.) Plant-parasitic nematodes in subtropical and tropical agriculture. CABI Publishing, Wallingford, UK.
Viggiano, J.R., L.G. Freitas, e P.A. Ferreira. 2012. Resíduo da produção de Pochonia chlamydosporia no desenvolvimento de mudas e plantas de alface. Pesquisa Agropecuária Brasileira 47:989-990. doi:10.1590/S0100-204X2012000700015.

Viggiano, J.R., L.G. Freitas, and E.A. Lopes. 2014. Use of Pochonia chlamydosporia to control Meloidogyne incognita in cucumber. Biological Control 69:72-77. doi:10.1016/j. biocontrol.2013.11.004. 